\title{
Opportunistic screening actions for breast cancer performed by nurses working in primary health care*
}

\author{
Rastreamento oportunístico do câncer de mama desenvolvido \\ por enfermeiros da atenção primária à saúde \\ Rastreo oportunista del cáncer de mama desarrollado por \\ enfermeros de la atención primaria de salud
}

Débora Cherchiglia de Moraes ${ }^{1}$, Ana Maria de Almeida ${ }^{2}$, Elisabeth Niglio de Figueiredo ${ }^{3}$, Edilaine Assunção Caetano de Loyola ${ }^{4}$, Marislei Sanches Panobianco ${ }^{5}$

How to cite this article:

Moraes DC, Almeida AM, Figueiredo EN, Loyola EAC, Panobianco MS. Opportunistic screening actions for breast cancer performed by nurses working in primary health care. Rev Esc Enferm USP. 2016;50(1):14-21. DOI: http://dx.doi.org/10.1590/S0080-623420160000100002

\footnotetext{
* Extracted from the dissertation "Ações de rastreamento oportunístico do câncer de mama implementadas por enfermeiros da Atenção Básica de Saúde de Ribeirão Preto-SP”, Programa de Pós-Graduação em Enfermagem em Saúde Pública, Escola de Enfermagem de Ribeirão Preto, Universidade de São Paulo, 2014.

${ }^{1}$ Universidade de São Paulo, Escola de Enfermagem de Ribeirão Preto, Programa de Pós-Graduação Enfermagem em Saúde Pública, Ribeirão Preto, SP, Brazil.

${ }^{2}$ Universidade de São Paulo, Escola de Enfermagem de Ribeirão Preto, Departamento de Enfermagem Geral e Especializada, Ribeirão Preto, SP, Brazil.

${ }^{3}$ Universidade Federal de São Paulo, Escola Paulista de Enfermagem, São Paulo, SP, Brazil.

${ }^{4}$ Universidade de Alfenas, Alfenas, MG, Brazil.

${ }^{5}$ Universidade de São Paulo, Escola de Enfermagem de Ribeirão Preto, Departamento de Enfermagem Materno-Infantil e Saúde Pública, Ribeirão Preto, SP, Brazil.
}

\section{ABSTRACT}

Objective: To identify opportunistic screening actions for breast cancer performed by nurses working in primary health care units in Ribeirão Preto, São Paulo. Method: Cross-sectional study with 60 nurses from 28 units, who had been working for at least one year in the public municipal health care network. Data were collected between December 2013 and March 2014, by means of a questionnaire, using descriptive analysis and the software IBM SPSS version 20 and Microsoft Excel 2010. Results: The results showed that $71.7 \%$ of the participants questioned their female patients as for risk factors for breast cancer, mainly during nursing consultation; $70.0 \%$ oriented users about the age to perform clinical breast exam, whereas $30.0 \%$ did not due to lack of knowledge and time; $60.0 \%$ explained about the age to perform mammogram; $73.3 \%$ did not refer patients with suspicious breast exam results to the referral department, citing scheduling as the main obstacle to referral. Educational activities were not performed by $78.3 \%$ of participants. Conclusion: Investment is needed in professional training and management of breast cancer screening.

\section{DESCRIPTORS}

Breast Neoplasms; Primary Health Care; Nurse's Role.
Corresponding author:

Débora Cherchiglia de Moraes

Av. dos Bandeirantes, 3900 - Monte Alegre CEP 14040-902 - Ribeirão Preto, SP, Brazil deboracherchiglia@hotmail.com
Received: 03/09/2015

Approved: 10/06/2015 


\section{INTRODUCTION}

According to GLOBOCAN 2012, breast cancer is the second most common cancer in terms of body location, with an incidence of 1.7 million new cases, or $11.9 \%$ of all cancers. Breast cancer is the fifth leading cause of death from cancer, with 522,000 (6.4\%) deaths, because it has a relatively favorable prognosis ${ }^{(1)}$. In Brazil, 57,120 new cases of the breast cancer are predicted for 2014-2015, along with high mortality rates - a result of tumors being detected at advanced stages ${ }^{(2)}$.

According to the Municipal Health Department of Ribeirão Preto, a municipality in the southeastern Brazilian state of São Paulo where this study was conducted, the mortality rate from breast cancer is increasing. The most recent data published show that in Ribeirão Preto in 2004, the mortality rate was 17.30 per 100,000 women, whereas in the state of São Paulo it was $14.08^{(3)}$.

Screening is paramount to control breast cancer, based on the systematic and periodic exams of asymptomatic women and early detection for symptomatic women, in order to diagnosis the disease in its early stages, when treatments are considered more effective, and the chances of curing the disease are greater ${ }^{(4)}$. However, the lack of infrastructure in public health services in Brazil impedes the deployment of organized screening programs, that generates high costs for mammography procedures, even with low coverage of this exam in the target population. Faced with these difficulties, actions for controlling breast cancer occur in isolation in the country ${ }^{(5)}$.

Breast cancer is important in the context of Brazilian public health policy, making clear the need for professional training, organization of health care services and educational activities for users. Investments in actions for prevention, early detection and implementation of effective programs to control the disease are key measures ${ }^{(1,6)}$. Organized screening programs, prevalent in wealthier countries, have greater potential to reduce morbidity and mortality and avoid unnecessary exams ${ }^{(6)}$; however, control and certification of screening programs implemented in the country still do not have consistent information about their effectiveness ${ }^{(7)}$.

The city of Curitiba, capital of the southern state of Paraná, has deployed an organized screening pilot project that is currently being evaluated. This project has adopted the guidelines of the "Control of Breast Cancer: Consensus Document", which recommends annual screening for all women starting at age 40 by means of the clinical breast exam (CBE); mammography, with an interval of at most two years between exams for women aged between 50 and 69 years; and, for women with a high risk of developing breast cancer, the Consensus Document recommends annual $\mathrm{CBE}$ and mammography starting at 35 years of age. Additionally, access to diagnosis, treatment and monitoring should be guaranteed for women with changes in results of breast exams ${ }^{(4)}$. In the rest of the country, opportunistic screening is adopted, which seeks to implement actions as recommended by the Consensus Document, but is not periodic and not all of the recommended actions are systematized.

Primary care is the structural setting for development of various actions to control malignant breast tumors, and constitutes the gateway of users to health care services. In addition, primary care is a good place to conduct educational activities ${ }^{(8)}$. Health care professionals working in primary care have a key role in developing these actions, especially nurses, who are the primary interface between health care staff and services users ${ }^{(9-10)}$.

The aim of this study was to identify opportunistic screening actions for breast cancer performed by nurses working in primary health care units (PCU) in Ribeirão Preto, São Paulo.

\section{METHOD}

This was a descriptive, cross-sectional study developed in PCU in the municipality of Ribeirão Preto. The study was part of the project titles "Actions for control of breast cancer: identification of primary care practices, a multicenter study conducted in partnership between the Paulista School of Nursing of the Federal University of São Paulo and Ribeirão Preto College of Nursing of the University of São Paulo.

The study population was nurses of both sexes working in PCU, who had been working in the public municipal health network for at least one year, and had experience in primary care. There was no age restriction for participants. Managers of the health care units were excluded from participating in the study.

Initially, 30 PCU in which 96 nurses worked were selected from the 42 operating in the municipality. The selection of PCU was random and according to the health production surveyed beforehand, and considered the following care unit types: traditional PCU, mixed PCU and Family Health Units (FHU). All nurses that met the inclusion and exclusion criteria were included in the study; 36 nurses were excluded, along with two health units whose nurses did not fit the inclusion criteria either. The sample was comprised of 60 nurses from 28 health units, who were invited and agreed to participate in the study. All study participants signed a free and informed consent form.

Data collection took place from December 2013 to March 2014, during the operating hours of the health care facilities and in accordance with nurses' availability.

A questionnaire consisting of 30 questions was used for data collection, structured according to specific primary health care actions in the Breast Cancer Control Program. The questionnaire included questions regarding: general information, time working in the health care network and the health unit, professional education and training, and actions for control of breast cancer. The questionnaire's content was validated by experts on the theme, and semantic validation was performed by nurses working in primary care in the southeast region of São Paulo ${ }^{(11)}$. 
The interviews in which the questionnaire was applied took place at a time scheduled by the nurses, and lasted about 40 minutes. The questionnaire was submitted to the researchers via the Internet, accessed at the health care units. In the units that did not have Internet access, the questionnaires were filled out on paper, and then the data were entered into a digital system; in these cases, double entry was performed on $10 \%$ of randomly selected questionnaires, and agreement between the two entries was considered excellent.

Descriptive analysis of data was performed, resulting in frequency tables for qualitative variables (ordinal or nominal), and the inclusion of the confidence interval for the proportion (CI 95\%), calculated from 1000 replicas by means of the bootstrap resampling method ${ }^{(12)}$. This process was conducted using the IBM software Statistical Package for the Social Sciences (SPSS), version 20.

Procedures for research with human subjects listed in the National Health Council Resolution 466/2012 were adhered to, and the study was approved by the research ethics committee of the Ribeirão Preto College of Nursing (CAAE protocol no: 16982513.7.1001.5393) and the Municipal Health Department of Ribeirão Preto ${ }^{(13)}$.

\section{RESULTS}

The 28 PCU were divided as follows: $20(71.4 \%)$ traditional PCU; 2 (7.1\%) mixed PCU, and 6 (21.4\%) FHU. Of the 60 nurses included in the sample, $42(70.0 \%)$ worked in traditional PCU, 6 (10.0\%) in mixed PCU and 12 (20.0\%) in FHU. The majority of nurses $(32-53.3 \%)$ had worked in the municipal health care network for more than 10 years, and $22(36.7 \%)$ had worked at their present PCU between five and ten years; $44(73.3 \%)$ were specialists in public health, 13 (21.7\%) had master's degrees, and only 3 (5.0\%) did not continue their education after completing their undergraduate degree. Some of the nurses had more than one type of specialization in health care.

Regarding professional training on the actions for control of breast cancer recommended by the Brazilian Ministry of Health (MOH), after 2004, half of the nurses $(29-48.3 \%)$ did not receive training, and of the 20 who confirmed that they had received training, 13 (65.0\%) had received it more than two years prior to the interview. Many of the nurses in this study could not provide information on the availability of the MOH's official documents for nursing consultation on actions to screen for mammary tumors, such as Basic Care Notebook No. 13 $(27-45.0 \%)$ and the Breast Cancer Consensus Document $(33-55.0 \%)$.

The majority $(43-71.7 \%)$ questioned their female patients on risk factors for breast cancer, primarily during nursing consultation. The nurses' questions were focused on factors such as personal or family history of breast cancer, in both sexes (43-100\%); personal or family history of ovarian cancer (34 - 79.1\%); smoking (38 - 88.4\%); exposure to pesticides and radiation $(30-69.8 \%)$; hormone replacement therapy $(39-90.7 \%)$; alcohol consumption
$(28-65.1 \%)$ and physical inactivity $(15-34.9 \%)$. The frequency of follow-up at a return visit was cited by the majority of nurses $(22-51.2 \%)$, and was between six months to one year.

In regard to frequency and age group for inclusion of $\mathrm{CBE}$ in primary care practice, it was observed that 28 (46.7\%) participants claimed that there was no standard frequency established for the exam, and 33 (55.0\%) said that there was no certain age to initiate this procedure, 42 (70.0\%) nurses reported advising their women patients about the age they should perform CBE, mainly during nursing consultation; and, 40 (95.2\%) participants reported requesting evaluation by a physician upon finding changes in the results of a woman's $\mathrm{CBE}$. Of the 18 nurses that did not perform $\mathrm{CBE}$, the primary reasons were lack of knowledge and time.

In regard to mammography (MMG), 36 (60.0\%) participants reported advising their patients about the age at which they must start the exam, and half recommended this exam after age 40. In terms of frequency, 27 (45.0\%) reported that the women should undergo MMG annually.

In terms of active search, 39 (65.0\%) nurses reported that they seek to contact patients with MMG results suspicious of malignant tumors, however, $46(76.7 \%)$ did not conduct active search for those who missed their scheduled MMG. The majority (44 to 73.3\%) of nurses did not forward users with suspicious MMG results to the health services referral department.

Regarding the duration of time between request for MMG and return of exam results to the PCU, most nurses (33-55.0\%) cited 1 to 3 months.

Some of the participants $(28-46.7 \%)$ stated that barriers exist to performing MMG, especially scheduling (20 - 71.4\%). In terms of request for MMG, 59 (98.3\%) reported that they had not requested it because according to municipal protocol, this activity is the responsibility of physicians (Table 1).

With regard to ultrasonography (USG) of breasts, the majority $(38-63.3 \%)$ of participants said there was no standard frequency established for the exam, whereas 20 (33.3\%) were unable to answer this question. More than half $(34-56.7 \%)$ of the nurses reported a delay in scheduling and period until return of exam results of more than 6 months.

The nurses cited the following difficulties in requesting this exam: difficulty in scheduling $(21-80.8 \%)$; lack of exam machine $(3-11.5 \%)$; lack of a physicial to perform the exam (4-15.4\%); and failure of the patient to appear on the scheduled date and time of the exam ( $8-30.8 \%)$. In terms of difficulties in assessing the results of the USG by the physician, 6 (10\%) cited delay in delivery of exam results to the health care unit.

The nurses' actions in regard to breast self-exam (BSE) are detailed in Table 2. 
Table 1 - Screening actions by means of MMG performed by nurses to control breast cancer - Ribeirão Preto, São Paulo, Brazil. December 2013 to March 2014.

\begin{tabular}{lcccc}
\hline Variable & $\begin{array}{c}\text { Absolute } \\
\text { Frequency }\end{array}$ & $\%$ & \multicolumn{2}{c}{$95 \% \mathrm{Cl}$} \\
& Lower & Higher \\
\hline
\end{tabular}

Frequency indicated for first MMG

$\begin{array}{lcccc}\text { Annual } & 27.0 & 45.0 & 31.6 & 58.8 \\ \text { Biannual } & 8.0 & 13.3 & 5.4 & 23.1 \\ \begin{array}{l}\text { There is no standard } \\ \text { frequency }\end{array} & 6.0 & 10.0 & 3.2 & 18.2 \\ \begin{array}{l}\text { Other frequency } \\ \text { 19.0 }\end{array} & 31.7 & 18.6 & 43.6\end{array}$

Recommended age for first mammogram

$\begin{array}{lcccc}<35 \text { years } & 2.0 & 3.3 & 0.0 & 8.8 \\ 35 \mid-40 \text { years } & 7.0 & 11.7 & 3.9 & 19.4 \\ 40 \mid-50 \text { years } & 30.0 & 50.0 & 37.0 & 63.0 \\ >50 \text { years } & 3.0 & 5.0 & 0.0 & 11.5 \\ \text { No age restriction } & 10.0 & 16.7 & 8.0 & 26.9 \\ \text { Does not remember } & 8.0 & 13.3 & 5.3 & 22.2\end{array}$

Orientation on age for first mammogram

$\begin{array}{lllll}\text { No } & 24.0 & 40.0 & 27.9 & 53.1 \\ \text { Yes } & 36.0 & 60.0 & 46.9 & 72.1\end{array}$

Time delay between request for MMG and return of exam results

$\begin{array}{lcccc}<1 \text { month } & 7.0 & 11.7 & 3.8 & 20.8 \\ 1 \text { to } 3 \text { months } & 33.0 & 55.0 & 42.1 & 68.1 \\ 3 \text { to } 6 \text { months } & 7.0 & 11.7 & 3.6 & 20.7 \\ \text { Other - specify } & 1.0 & 1.6 & 0.0 & 5.7 \\ \text { Does not remember } & 12.0 & 20.0 & 10.6 & 30.6\end{array}$

CI: confidence interval based on 1000 bootstrap samples. Source: Research data

Note: $n=60$.

Table 2 - Screening actions performed by means of BSE performed by nurses to control breast cancer - Ribeirão Preto, São Paulo, Brazil. December 2013 to March 2014.

\begin{tabular}{lccc}
\hline Variable & $\begin{array}{c}\text { Absolute } \\
\text { Frequency }\end{array}$ & \multirow{2}{c}{$\mathrm{Cl} 95 \%$} \\
& Lower & Higher \\
\hline
\end{tabular}

Teaches patients how to self examine their breasts $(n=60)$

$\begin{array}{lllll}\text { No } & 18.0 & 30.0 & 17.9 & 41.8 \\ \text { Yes } & 42.0 & 70.0 & 58.2 & 82.1\end{array}$

Teaching time Pap collection $(n=42)$

$\begin{array}{lllll}\text { No } & 19.0 & 45.2^{*} & 30.2 & 60.5 \\ \text { Yes } & 23.0 & 54.8^{*} & 39.5 & 69.8\end{array}$

Nursing consultation $(\mathrm{n}=42)$

$\begin{array}{lcccc}\text { No } & 5.0 & 11.9^{*} & 2.9 & 22.7 \\ \text { Yes } & 37.0 & 88.1^{*} & 77.3 & 97.1\end{array}$

In case of specific complaint $(\mathrm{n}=42)$

$\begin{array}{lcccc}\text { No } & 1.0 & 2.4^{*} & 0.0 & 7.9 \\ \text { Yes } & 41.0 & 97.6^{*} & 92.1 & 100\end{array}$

Home visits $(n=42)$

\begin{tabular}{ccccc} 
No & 27.0 & $64.3^{*}$ & 50.0 & 78.4 \\
\hline
\end{tabular}

...continuation

\begin{tabular}{ccccc}
\hline \multirow{2}{*}{ Variable } & $\begin{array}{c}\text { Absolute } \\
\text { Frequency }\end{array}$ & $\%$ & \multicolumn{2}{c}{ Cl 95\% } \\
Lower & Higher \\
\hline Yes & 15.0 & $35.7^{*}$ & 21.6 & 50.0 \\
Age group to start BSE $(\mathrm{n}=42)$ & & & \\
$\quad$ Upon menstruation & 22.0 & 52.3 & 36.8 & 66.7 \\
<35 years & 2.0 & 4.8 & 0.0 & 13.2 \\
35 to 40 years & 2.0 & 4.8 & 0.0 & 12.5 \\
>40 years & 2.0 & 4.8 & 0.0 & 11.1 \\
No age restriction & 14.0 & 33.3 & 20.0 & 47.8
\end{tabular}

Frequency with which a patient is advised to perform BSE $(n=42)$

$\begin{array}{lcccc}\begin{array}{l}\text { There is no standard } \\ \text { frequency }\end{array} & 8.0 & 19.0 & 7.5 & 31.2 \\ \text { Monthly } & 33.0 & 78.6 & 66.7 & 90.6 \\ \text { Bimonthly } & 1.0 & 2.4 & 0.0 & 8.3\end{array}$

Reason for not advising

Knowledge deficiency $(n=18)$

$\begin{array}{lcccc}\text { No } & 17.0 & 94.4^{*} & 81.2 & 100 \\ \text { Yes } & 1.0 & 5.6^{*} & 0.0 & 18.8\end{array}$

Lack of appropriate location $(\mathrm{n}=18)$

$\begin{array}{lcccc}\text { No } & 13.0 & 72.2^{*} & 50.0 & 93.3 \\ \text { Yes } & 5.0 & 27.8^{*} & 6.7 & 50.0\end{array}$

Lack of time $(\mathrm{n}=18)$

$\begin{array}{lcccc}\text { No } & 14.0 & 77.8^{*} & 57.9 & 95.0 \\ \text { Yes } & 4.0 & 22.2^{*} & 5.0 & 42.1\end{array}$

Other reason $(\mathrm{n}=18)$

\begin{tabular}{lcccc} 
No & 1.0 & $5.6^{*}$ & 0.0 & 17.6 \\
Yes & 17.0 & $94.4^{*}$ & 82.4 & 100.0 \\
\hline
\end{tabular}

CI: confidence interval based on 1,000 bootstrap samples. Source: Research data.

*Note: each frequency was calculated by total responses.

As for computerized systems deployed in the PCU, 47 (78.3\%) nurses cited the Primary Care Information System (Sistema de Informação da Atenção Básica - SIAB) and 43 (71.7\%) the Cancer Information System (Sistema de Informação de Câncer - SISCAN). In regard to planning organized screening actions from data generated in the systems, $19(31.7 \%)$ responded negatively, $25(41.7 \%)$ positively, and 16 (26.7\%) did not respond. The 25 (41.7\%) nurses who responded positively reported using data generated by the systems for estimating coverage; providing resources for actions; knowing the characteristics of the women to whom they were providing care; doing an active search and providing educational activities.

Only 7 (11.7\%) nurses stated that the PCU where they worked made the Woman's Schedule available. The availability and filling out of this Schedule are important in the comprehensive care of women's health, providing health history, results of exams and treatments performed, in addition to scheduling appointments and tests.

All of the participants reported that they performed nursing consultations, including breast cancer screening ac- 
tions, and 54 (90.0\%) performed less than 10 consultations daily. As regards educational activities on breast cancer in the PCU, 47 (78.3\%) reported that they did not perform this action.

\section{DISCUSSION}

Most of the participants had professional experience in primary care, had worked in this field for more than 10 years, and had studied a specialization in public health.

Similar results were identified in surveys conducted with nurses working in primary care in Brazilian municipalities. Although few of the nurses had graduate education at the stricto sensu level, some of them had lato sensu specialization courses, most of which were in the fields of public and family health ${ }^{(14-15)}$.

International studies have shown that the increased knowledge of nurses is associated with their professional experience and completion of courses after undergraduate training, and stress the importance of professional training and constant updating of knowledge for effective control of mammary tumors ${ }^{(16-18)}$.

Despite the evidence that knowledge of nurses is related to professional experience and completion of courses, for the present study, in which most of the study participants had professional experience and had studied public health at the graduate level, there was a lack of knowledge of screening actions for breast cancer, a topic included in the priority public policy for primary care, agreed to by the municipalities.

This gap in knowledge may be related to the fact that the nurses in the municipal PCU in Ribeirão Preto still favor care of women during pregnancy and early motherhood, to the detriment of control of breast cancer. It was observed that the nursing professionals in the study sample were insecure to perform screening actions in the PCU where they worked, either due to unfamiliarity with these actions or the predominant care model in the municipality, that continues to favor the complaint-conduct model.

Lack of knowledge about actions for screening was also found in one study of nurses working at a public hospital in the southern state of Rio Grande do Sul, in which the authors concluded that the nurses were not familiar with the protocols defined by the $\mathrm{MOH}$, nor priority programs such as control of breast cancer ${ }^{(19)}$.

In addition, there was a lack of professional training among the participants, and many of the nurses did not participate in courses to keep their knowledge and information up to date, and were not aware of the availability of the documents provided by the $\mathrm{MOH}$, such as the Primary Care Handbook No. 13 and the Breast Cancer Consensus Document. Although many of the nurses that participated in the present study had expertise on public health, they were not aware of actions recommended for control of breast cancer. According to the guidelines of the $\mathrm{MOH}$, these documents must be accessible for consultation in order to perform daily, routine work by these health care workers ${ }^{(4)}$.

In regard to risk factors for breast cancer, most of the nurses stated that they question their patients on these, pri- marily during nursing consultation. These professionals' actions represent a major step for identification of women at high risk for the disease, and prioritization of these women for actions for screening and early detection ${ }^{(8)}$.

Most of the nurses who participated in this study and investigated risk factors for breast cancer said that followup of high risk women was performed upon the patient's return visit 6 months to 1 year later. It is worth noting that annual monitoring is recommended by the $\mathrm{MOH}$ for women with high risk of breast cancer ${ }^{(4)}$.

When questioned about CBE, most of the participants said that they advised their patients in regard to the age at which they should undergo this exam; however, a significant portion of them were unaware of the frequency with which $\mathrm{CBE}$ should be performed nor age to start this exam. Thus, lack of training seems to lead nurses to implement actions that are not in line with established public policies for breast cancer screening.

Studies have shown errors or ignorance of primary care professionals in regard to the practice and implementation of $\mathrm{CBE}^{(20-23)}$.

International studies on mammography affirm that a satisfactory relationship between professionals and users of health services is essential for adherence to breast cancer screening exams, and that the quality of the care provided by nurses is important to motivate adherence by female public health users to these exams ${ }^{(17-18)}$.

The results of the present study indicate that most of the participant nurses actively sought to contact patients that did not return for the exam result with MMG results suspicious of malignant tumor; however, most of the nurses did not seek out women who did not appear for the mammogram exam. The nurses said that they were unable to keep track of users' adherence since the exam was performed outside of the PCU.

Active search to contact patients is an important strategy to expand women's adherence to breast cancer screening exams. According to the $\mathrm{MOH}$, for effective actions of the program to control this cancer, it is necessary to fulfill the coverage goals of the target population and adhere to the proper frequency of the exam, in addition to appropriate monitoring of health care users ${ }^{(23)}$.

In this sense, an important finding from this study is that $44(73.3 \%)$ participants did not refer women with suspected malignancy to referral departments, but emphasized that in the municipality of Ribeirão Preto, this action is the responsibility of physicians. This fact may result in missed early-stage diagnosis, because further diagnosis and evaluation with a specialist may be delayed.

In regard to information about MMG, most of the nurses interviewed said that they advise women about the age at which they should start undergoing this exam. Half of the participants mentioned that the first MMG must occur between 40 and 50 years of age, whereas 27 (45.0\%) said that they advise women to perform this exam annually.

The nurses' orientation to begin undergoing MMG at 40 years of age may be related to the fact that the municipal protocol expanded the age range of biannual MMG for all 
women aged between 40 and 69 years. This protocol is in accordance with the guidelines of the Brazilian Society of Mastology, which diverges from that of the MOH. Indeed, there are controversies over age to start $\mathrm{MMG}^{(24)}$.

A recently published randomized study in Canada, with 89,835 women, disclosed data from more than 25 years of monitoring, and compared breast cancer mortality in women aged between 40 and 59 years that did or did not undergo screening by mammography. The study concluded that screening by mammography starting at age 40 should be reviewed, as there is no significant difference in mortality of women in this age group who underwent mammography compared with those who did not. The study also identified that the regular performance of MMG starting at age 40 increases the number of diagnoses of the disease; consequently, women with breast cancer undergo aggressive treatments that are often unnecessary, since of the women participants in the study cited above, 1 of every 5 cases of mammary neoplasia discovered by MMG had little chance of progressing. Regardless, the authors claim that the findings of their study should not be generalized to all countries ${ }^{(25)}$.

In the face of these controversies, efforts must be made to deploy programs for organized screening for breast cancer, since this will enable greater systematization of actions that prioritize women at high risk for the disease.

Most of the nurses that participated in the present study reported advising their patients on BSE, yet the appropriate period for this practice was unknown to many of the participants. Although BSE is not an effective action for breast cancer screening, in countries where actions are not systematized, this practice continues to be necessary so that women with symptoms seek health care services as soon as they perceive any sign or symptom in their breasts.

The present study observed that nurses should advise users on frequency and initiation of BSE, teach this technique, and observe whether their patients are performing it properly, so that they can discover early changes in their breasts, and consequently detect tumors earlier ${ }^{(26)}$. One study conducted in Mexico emphasized the importance of nurses to teach BSE and perform $\mathrm{CBE}$, and stated that nurses have a major role in the development of prevention programs, and that BSE and CBE are important strategies to detect and diagnose breast cancer in countries without resources to expand screening by means of $\mathrm{MMG}^{(27)}$.

In addition to these screening actions for breast cancer, deployment and correct usage of information systems in PCU are essential to monitor the pathology and control the disease $\mathrm{e}^{(28)}$.
According to the $\mathrm{MOH}$, information systems are fundamental to plan actions for early diagnosis and screening of breast tumors, because they are an essential tool for articulation between health care services ${ }^{(8)}$. However, the present study observed a lack of training and knowledge of the participants in regard to availability of information systems in PCU and how to use them, in particular the SIAB and SISCAN.

It is worth mentioning that some of the professionals interviewed did not know the availability of the Woman's Schedule in the PCU in which they worked, and the majority did not perform educational activities on breast cancer. Added to other issues already pointed out above, this denotes some flaws in the care of women by nurses working in the municipal public primary health care services in Ribeirão Preto, contrary to specifications of the $\mathrm{MOH}$, and that may affect actions for prevention and control of breast cancer.

\section{CONCLUSION}

The results of this study showed positive and negative aspects in regard to screening actions for breast cancer by the primary care nurses interviewed for this study. Most of the nurses $(71.7 \%)$ claimed to question the women on risk factors, but did not know that the monitoring of women at high risk for breast cancer should be performed annually. All of the participants oriented women on the frequency with which they should perform $\mathrm{CBE}$ and the age to start undergoing this exam, most $(75.0 \%)$ of the nurses provided incorrect directions on frequency and age group (93.3\%). The majority $(65.0 \%)$ of participants actively sought out women with MMG report suspicious of malignancy, and those patients that did not return for their exam result; however, $76.7 \%$ did not seek out women who missed their scheduled mammogram. Half of the participants (50.0\%) advised their patients that they should undergo their first MMG between 40 and 50 years of age, whereas 27 (45.0\%) said that they advised women to undergo this exam annually. Most (70.0\%) of the nurses advised users of primary care services on BSE; however, the appropriate period for this practice was unknown to $21.4 \%$ of those who provided this instruction. There is a lack of training and knowledge of nurses on the availability of information systems and their use, and on the availability of the Women's Schedule in the PCU where they worked.

In conclusion, in order to adapt and improve nurses' screening actions for breast cancer, investments are needed in ongoing education of nurses, and continuous evaluation of screening actions in the PCU of Ribeirão Preto.

\section{RESUMO}

Objetivo: Identificar as ações de rastreamento oportunístico do câncer de mama realizadas por enfermeiros de unidades básicas de saúde (UBS) de Ribeirão Preto. Método: Estudo transversal, com 60 enfermeiros de 28 Unidades, atuantes há um ano na rede municipal de saúde. Os dados foram coletados entre dezembro de 2013 e março de 2014, por meio de formulário, analisado descritivamente, utilizando os softwares IBM SPSS 20 e Excel 2010. Resultados: Apontaram que 71,7\% realizam investigação sobre os fatores de risco do câncer de mama, principalmente durante a consulta de enfermagem; 70,0\% orientam a mulher acerca da idade para realizar Exame Clínico das Mamas; 30,0\% deles não o realizam por falta de conhecimento e tempo; 60,0\% explicam sobre a idade para realização 
da mamografia; 73,3\% não encaminham as usuárias com resultado suspeito à unidade de referência, alegando o agendamento como principal entrave para sua execução. As atividades educativas não são realizadas por 78,3\% dos profissionais. Conclusão: Há necessidade de investimentos em capacitação profissional e gerenciamento dos serviços de saúde.

\section{DESCRITORES}

Neoplasias da Mama; Atenção Primária à Saúde; Papel do Profissional de Enfermagem.

\section{RESUMEN}

Objetivo: Identificar las acciones de rastreo oportunista del cáncer de mama llevadas a cabo por enfermeros de unidades básicas de salud (UBS) de Ribeirão Preto. Método: Estudio transversal, con 60 enfermeros de 28 Unidades, actuantes desde hace un año en la red municipal de salud. Los datos fueron recogidos entre diciembre de 2013 y marzo de 2014, mediante formulario, analizado descriptivamente empleándose los softwares IBM SPSS 20 y Excel 2010. Resultados: Señalaron que el 71,7\% realizaron investigación acerca de los factores de riesgo del cáncer de mama, especialmente durante la consulta de enfermería; el 70,0\% orientan a la mujer con respecto a la edad para realizar el Examen Clínico de las Mamas; el 30,0\% de ellos no lo realizan por falta de conocimiento y tiempo; el 60,0\% explican sobre la edad para la realización de la mamografía; el 73,3\% no derivan a las usuarias con resultado sospechoso a la unidad de referencia, alegando la programación como principal obstáculo para su ejecución. Las actividades educativas no las llevan a cabo el 78,3\% de los profesionales. Conclusión: Existe necesidad de inversiones en capacitación profesional y gestión de los servicios sanitarios.

\section{DESCRIPTORES}

Neoplasias de la Mama; Atención Primaria de Salud; Rol de la Enfermera.

\section{REFERENCES}

1. Ferlay J, Soerjomataram I, Dikshit R, Eser S, Mathers C, Rebelo M, et al. Cancer incidence and mortality worldwide: sources, methods and major patterns in GLOBOCAN 2012. Int J Cancer. 2015;136(5):E359-86.

2. Brasil. Ministério da Saúde; Instituto Nacional de Câncer José de Alencar. Estimativa 2014: incidência de câncer no Brasil. Rio de Janeiro: INCA; 2014.

3. Ribeirão Preto. Secretaria Municipal de Saúde. Plano Municipal de Saúde de Ribeirão Preto: período 2005-2008 [Internet]. Ribeirão Preto: PMRP; 2005 [citado 2013 abr. 15]. Disponível em: http://www.ribeiraopreto.sp.gov.br/ssaude/vigilancia/planeja/plano05-08.pdf

4. Brasil. Ministério da Saúde. Instituto Nacional de Câncer José de Alencar. Programa Nacional de Controle do Câncer de Mama. Rio de Janeiro: INCA; 2011.

5. Silva TB, Mauad EC, Carvalho AL, Jacobs LA, Shulman LN. Difficulties in implementing an organized screening program for breast cancer in Brazil with emphasis on diagnostic methods. Rural Remote Health [Internet]. 2013 [cited 2015 Mar 28];13: 2321. Available from: http:// www.rrh.org.au/articles/subviewnew.asp? ArticlelD=2321

6. Azevedo e Silva G, Bustamante-Teixeira MT, Aquino EML, Tomazelli JG. Santos-Silva I. Acesso à detecção precoce do câncer de mama no Sistema Único de Saúde: uma análise a partir dos dados do Sistema de Informações em Saúde. Cad Saúde Pública. 2014;30(7):1537-50.

7. Tiezzi DG. Câncer de mama: um futuro desafio para o sistema de saúde nos países em desenvolvimento. Rev Bras Ginecol Obstet. 2010;32(6):257-9.

8. Brasil. Ministério da Saúde; Secretaria de Atenção à Saúde, Departamento de Atenção Básica. Controle dos cânceres do colo do útero e da mama. $2^{\text {a }}$ ed. Brasília; 2013.

9. Silva SA, Nogueira DA, Paraizo CMS, Fracolli LA. Assessment of primary health care: health professionals' perspective. Rev Esc Enferm USP [Internet]. 2014 [cited 2015 Mar 28]; 48(n. spe): 122-8. Available from: http://www.scielo.br/pdf/reeusp/v48nspe/0080-6234-reeusp48-esp-126.pdf.

10. Lourenço TS, Mauad EC, Vieira RAC. Barreiras no rastreamento do câncer de mama e o papel da enfermagem: revisão integrativa. Rev Bras Enferm. 2013;66(4):585-91.

11. Marques CA, Figueiredo EM, Gutiérrez MG. Validação de instrumento para identificar ações de rastreamento e detecção de neoplasia de mama. Acta Paul Enferm. 2015; 28(2):183-9.

12. Efron B, Tibshirani RJ. An introduction to the bootstrap. New York: Chapman \& Hall/CRC; 1993.

13. Brasil. Ministério da Saúde; Conselho Nacional de Saúde. Resolução n. 466, de 12 de dezembro de 2012. Dispõe sobre as diretrizes e normas regulamentadoras de pesquisas envolvendo seres humanos [Internet]. Brasília; 2012 [citado 2014 set. 22]. Disponível em: http:// conselho.saude.gov.br/resolucoes/2012/Reso466.pdf.

14. Beck CLC, Prochonow A, Silva RM, Prestes FC, Tavares JP. Fatores que favorecem e dificultam o trabalho dos enfermeiros nos serviços de atenção a saúde. Esc Anna Nery Rev Enferm. 2010;14(3):490-5.

15. Corrêa ACP, Araújo EF, Ribeiro AC, Pedrosa ICF. Perfil sociodemográfico e profissional dos enfermeiros da atenção básica à saúde de Cuiabá - Mato Grosso. Rev Eletr Enferm [Internet]. 2012 [citado 2015 mar. 22];14(1):171-80. Disponível em: http://www.fen.ufg.br/revista/ $\mathrm{v} 14 / \mathrm{n} 1 / \mathrm{v} 14 \mathrm{n} 1 \mathrm{a} 20 . \mathrm{htm}$

16. Andsoy II, Gul A. Breast, cervix and colorectal cancer knowledge among nurses in Turkey. Asian Pac J Cancer Prev. 2014;15(5):2267-72.

17. Alipour S, Jannat F, Hossdeini L. Teaching breast cancer screening via text messages as part of continuing education for working nurses: a case-control study Bangkok. Asian Pac J Cancer Prev. 2014;15(14):5607-9.

18. Fotedar V, Seam RK, Gupta MK, Guota M, Vats S, Verma S. Knowledge of risk factors \& early detection methods and practices towards breast cancer among nurses in Indira Gandhi Medical College, Shimla, Himachal Pradesh, India. Asian Pac J Cancer Prev. 2013;4(1):117-20. 
19. Prolla CMD, Silva OS, Oliveira Netto CB, Goldim JR, Ashton-Prolla P. Knowledge about breast cancer and hereditary breast cancer among nurses in a public hospital. Rev Latino Am Enferm. 2015;23(1):90-7.

20. Cavalcante SAM, Silva FB, Marques CAV, Figueiredo EN, Gutiérrez MGR. Ações do enfermeiro no rastreamento e diagnóstico do câncer de mama no Brasil. Rev Bras Cancerol. 2013;59(3):459-66.

21. Jácome EM, Silva RM, Gonçalves MLC, Collares PMC, Barbosa IL. Detecção do câncer de mama: conhecimento, atitude e prática dos médicos e enfermeiros da Estratégia Saúde da Família de Mossoró, RN. Rev Bras Cancerol. 2011;57(2):189-98.

22. Oluwatosin O. Primary health care nurse`s knowledge practice and client teaching of early detection measures of breast cancer in Ibadan. BMC Nursing. 2012;11:22.

23. Barreto ASB, Mendes MFM. Avaliação de uma estratégia para ampliar a adesão ao rastreamento do câncer de mama no Nordeste brasileiro. Rev Bras Ginecol Obstet. 2012; 34(2):86-91.

24. Ribeirão Preto. Prefeitura Municipal. Programa de Assistência Integral à Saúde da Mulher [Internet]. Ribeirão Preto: PMRP; 2013 [citado 2014 jun. 20]. Disponível em: http://www.saude.ribeiraopreto.sp.gov.br/ssaude/programas/mulher/i16indice.php

25. Miller AB, Wall C, Baines CJ, Sun P, To T, Narod Steven A. Twenty five year follow-up for breast cancer incidence and mortality of the Canadian National Breast Screening Study: randomised screening trial. BMJ. 2014;348:g366.

26. Nichols M. The nurse's role in self-breast examination education. Plast Surg Nurs. 2012; 32(4):143-5.

27. López-Carrillo L, Torres-Sánchez L, Blanco-Muñoz J, Hernández-Ramírez RU, Knaul FM. Utilización correcta de las técnicas de detección de cáncer de mama en mujeres mexicanas. Salud Pública Méx [Internet]. 2014 [citado 2015 Jun. 28];56(5):538-64. Disponible en: http:// www.scielo.org.mx/pdf/spm//v56n5/v56n5a21.pdf

28. Vidor CA, Fisher PD, Bordin R. Use of health information systems in small municipalities in Southern Brazil. Rev Saúde Pública. 2011;45(1):24-30. 